\title{
Essay Writing Skill of the Fourth Semester Students of STKIP PGRI Bandar Lampung
}

\author{
Tri Riya Anggraini* \\ Indonesian Language and Literature Study \\ Program, Faculty of Teacher Training and \\ Education \\ STKIP PGRI Bandar Lampung, Indonesia \\ tri260211@gmail.com
}

\author{
Hastuti \\ Indonesian Language and Literature Study \\ Program, Faculty of Teacher Training and \\ Education \\ STKIP PGRI Bandar Lampung, Indonesia \\ Hastuti@gmail.com
}

\author{
Frieska Maryova Rachmasisca \\ Indonesian Language and Literature Study \\ Program, Faculty of Teacher Training and \\ Education \\ STKIP PGRI Bandar Lampung, Indonesia \\ Yova041188@gmail.com
}

\begin{abstract}
The problem raised in this study is about the ability and difficulty in writing essays. Research used a descriptive method. Data obtained from the essay writing task with the topic that has been provided, then the data are analyzed. The subject in this study were 25 students. From the results of the analysis in terms of authenticity and logic, the completeness of the essay, the contents of the essay, as well as language and writing can be stated to have good ability. With some difficulties in writing the most dominant essays in terms of language and writing with the contents of the essay.
\end{abstract}

Keywords--skill, writing, essay.

\section{INTRODUCTION}

This study examines essay writing. This is because of the interest to explore experiences and knowledge related to the topic of writing. It was realized that writing was not as easy as public speaking. When talking about public speaking theories, someone does not pay attention to the use of appropriate language, appropriate punctuation function, sometimes he or she slips the regional or everyday languages. Inversely when writing. It requires skills in processing a word into an effective sentence, then making it a slick discourse. Not only skillful in processing words and sentences, the author should have skill in using punctuation based on its function.

Writing skills must be supported with a high will and intelligence (HS, 2005). Willingness is the beginning of improving writing skills. The low students' writing skill is caused by the lack of reading activity (Widiati, 2008). Writing skill is the most difficult language skill. Writing skill cannot be taught, but must be trained patiently, painstakingly and intensively, starting from preparation, writing draft, revision, and publication (Connor, 1996). In fact, the desires and abilities of the fourth semester students of STKIP PGRI Bandar Lampung are related to essay writing, information showed that 1) the students felt strange by narration writing, 2) the students did not know about narrative writing, and 3) the observations of researchers related to student writing assignments, it found that some writing were lacks focus with one idea, and punctuation which was not suitable with its function. So, the researchers were interest to conduct a research related to writing essays so that students could train themselves to pursue writing activities. The purpose of this research was to know and describe about essay writing skill and trouble of the fourth semester students of STKIP PGRI Bandar Lampung.

Writing is a productive competency which can be developed by practicing and treatment as well as someone' talent. This skill is certainly different from speaking skill. In terms of rules, spoken language tends to be more laxer and not too bound. Meanwhile, in writing, it takes rules related to spelling. With this comparison, writing is not a written / spoken variety. (Krashen, 1981; Slamet, 20017) it is said that the activity of writing not only form thoughts or feelings, but also the expression of ideas, knowledge science, and life experiences of a person in written language.

Writing is a complex cognitive activity because it requires control of a number of variables simultaneously, besides that it requires experience, time, opportunity, training in learning to write both poetry, short stories, drama texts and all need a process and cannot be mastered by students themselves (Nunan, 1989; Tarigan, 2008; Rachmawati, 2014)

Writing activities convey ideas, messages, information by taking notes or speaking by using paper or computer (Satata, 2012; Meyers, 2005; Dalman, 2011). In other words, writing activity cannot be done easily, not necessarily able to write well. There are two things needed by writers to get good writing result, first, in order to produce good writing, it takes process, time, and continue to practice writing. Second, writing requires plan, ideas, or even feelings, and this will be gained from the experience of oneself, others, both read and heard.

An essay is "a piece of writing or short story in the form of prose, which discusses a problem or issue in passing at a glance based on the personal point of view or interest of the author about the problem or issue written concisely (Depdikbud, 1995; Budiyono, 2012; Djuharie, 2001). Essays are part (a piece) of an article, but it can also be interpreted as an intake short essay (Khuzaemah, 2017). Based on this statement, it can be revealed that the essay is a short article containing the ideas or opinions of the author relating to the ongoing phenomenon. From essay writing, the reader will be able to judge or measure the intelligence of the writer. Writers who are knowledgeable will be able to convey their ideas coherently, logically, and attractively and readers can easily 
understand the opinions of writers. Ideas delivered in a coherent, logical and systematic way require intelligence in the field of linguistics. Someone's linguistics is better accompanied by a high reading level. So that the more intellectual someone is in reading, the better writing, ideas, and linguistics will be.

There are some essay structures, namely the mechanical part, content, organizing, and sentence structure. In the mechanical structure, an essay must be written with punctuation and spelling that is appropriate and appropriate, this aims to facilitate the reader in understanding the meaning of the sentence set forth by the writer in his essay (Oshima, 2006). On the content side, the essay must clearly describe an interesting topic to discuss. The topic raised in the essay must be implicitly seen in the opening paragraph of the thesis statement. Next, the problem in the thesis statement is developed in the body of the essay by adding facts, examples, and arguments / opinions that convince the readers.

Another structure in building a good essay is the organization of the writing itself (Helaluddin, 2017). This section is related to the framework or outline used in writing. In essay, writing framework consists of three parts, namely opening paragraph, some paragraphs in essay body, and closing paragraph. In the opening paragraph, the essay begins with an outline of the topic and concludes on a more specific essay topic and ends with one sentence as a thesis statement. In the body of essay, each paragraph discusses the points stated in thesis statement, supported by supporting material (facts, examples, and arguments), has unity and cohesion, and the use of transition marks used as a liaison between paragraphs

Writing is part of four language skills which are also a process. Writing is a creative process which must be carried out in stages (Anggraini, 2018; Suparno, 2007) states the stages or process of writing are broadly divided into three stages, namely pre-writing, writing, and post-writing. There are five steps in the application to the process approach learning model, namely: (a) prewriting, (b) drafting (c) revising, (d) editing, and (e) publishing (Wahyudi, 2016; Zainurrahman, 2011).

Based on this theory, it can be said that the stages in writing are, before, during writing and after writing. The stage before writing, a person must have skill in finding ideas, ideas or topics which will be made into a written framework and then developed in writing. When writing, someone will write in accordance with the framework of writing, and developed into several paragraphs with a unified topic of discussion. The last step is revising, editing and publishing after it is ready to publish.

Writing steps can be summarized as follows (Dalman, 2012): determine the theme or topic; outlining or outline the ideas that we will discuss; write our opinions as authors with clear and clear sentences; body writing essay; start by sorting out the important points to be discussed, then make a few subtopics for discussion to make it easier for readers to understand the purpose of our ideas as authors, then we must develop the sub-themes that we have previously made; make the first paragraph as an introduction. That is why, what we will write must be the reason or background for the reason we wrote the essay; write a conclusion. This is important because in order to form the opinions of readers we must draw conclusions from our ideas as writers. Because it is the task of essay writers. It is different from news writers in mass media who should be neutral; and we should put finishing touches on our writing so that readers feel they can get benefit from what we write easily and systematically so that they can create complete framework.

\section{METHOD}

This study used descriptive method. According to (Sukmadinata, 2011) descriptive research is the most basic type of research which describes natural and non-natural phenomena. Furthermore, (Darmadi, 2011) also described that descriptive research is non-experimental research because researchers do not control and manipulate research variables. The purpose of this type of research is to obtain information about problems / phenomena in compiling essays experienced by the students

The research design used by this researcher did not aim to test the truth of certain hypotheses. In other words, there were other data which would be obtained in this type of research, among others, to describe the information which was available related to certain variables and symptoms and constraints studied. After the data had been collected, the researcher described various aspects concerning the essay mistakes made by the students. The data was explained qualitatively by describing narrative accompanied by a description of what was found in the study.

The subjects of this study were essays made by fourth semester students totalling 25 students. The object of this research is the ability and difficulty in writing essays in terms of the authenticity and logic of the essay, the completeness of the essay, the content of the essay, as well as language and writing.

\section{RESULTS \& DISCUSSION}

The results of the study include the following three things; (a) Authenticity and logic of the essay, (b) Completeness of the essay, (c) essay content, (d) language and writing. The following will be discussed as below.

\section{A. Originality and logic of Essay}

In general, essays written by students differed according to quality, type, length, style, and subject. They also existed in the form of simple to very complex, but all of them showed a personal opinion as a final analysis. Written essay did not just show facts or tell an experience; but also slipped the writer's opinion between the facts and experiences. Not just an opinion in writing an essay. However, it must be understood what was 
actually meant by the opinion, how to convey it, and how to express its value.

The most common mistakes made by students are ineffectiveness of sentences, no cohesion and coherence between paragraphs. Errors in cohesion, coherence, and ineffectiveness of sentences are caused by the choice of conjunctions used to combine paragraphs or between sentences. So when reading a student's writing, it must be repeated so that the reader understands.

\section{B. Essay Completness}

In general, in writing an essay based on the completeness of the essay there were opinions, views, or personal expressions of an author which were poured into written form. This paper was a combination of scientific articles and opinions. The essay did not only contain opinions, but a combination of facts, knowledge and imagination or feelings of the author.

Completed essays contain opinions, facts and feelings written in three parts, namely the introduction, content, and closing. Each of these paragraphs has subsections that must be presented systematically and well.

In the opening paragraph, good writers should present interesting ideas and present preliminary information. The error that occurred was that the student had not presented an idea that caught the reader's attention even though he had presented a bit of initial information.

The error that occurs is to have one opening paragraph, several paragraphs in the content of the essay, and one closing paragraph. Some students write essays with two opening paragraphs, the contents of the essay are too long in describing the idea of the topic. There is also an essay that contains the contents of only one essay, this certainly does not describe opinions, facts which should be clearly stated.

Another mistake is that there is no opening paragraph, the topic exposure has been written at the beginning of the paragraph up to the paragraph. This error is classified as fatal because the final paragraph does not help the reader to know in general the topics discussed. Some other essays, describing closing paragraphs tend to be still common.

\section{Essay Content}

Essay content was elaborated by students from the main ideas stated in the sentence. The translation of the main ideas was manifested in several paragraphs. It consisted of several main ideas. Each main idea was written and elaborated in one paragraph. Each content paragraph discussed more specific and more detailed ideas so that the argument became more convincing. More specific ideas were supporting sentences which served as a logical explanation of the arguments presented by the author. Arguments in content paragraphs were carefully organized or managed. Each explanatory sentence which was written had close relevance to the idea. In addition, the movement between one content paragraphs with another content paragraph was carefully designed. Arrangement of content paragraphs arranged in chronological order, logical, or importance.

Based on the results of the analysis, the benchmark in the content of the essay is the selection of the topic that will be lifted in the writing. Topic choices become very important in the reader's interest. Researchers provide a topic/theme choice to students who are common and close to life. While students are required to be smart in narrowing the topic so that it becomes an interesting choice of titles to be written and read. From the choice of themes/topics, students are also able to connect to the latest problems that concern the audience today. There are some interesting topics selected by the students in the essay, among others: the benefits of social media in business, character education for students, combining religious teachings in character education, and the impact of social media for the community.

The biggest mistake that is to choose a theme that is in fact does not fit the life experience so it is difficult to write a view related to the theme that has been chosen. Another mistake is that the chosen theme is not logical with the contents described, so the content in the essay is not appropriate. Another mistake of not chronologically a topic between paragraphs makes the reader must repeatedly when reading to get the idea written.

\section{Language and Writing System}

In some data obtained from students' essay writing results, it was also found that they put conjunction at the beginning of the sentence. The conjunction was and, or, whereas, so and others. There were many students who put the connecting words at the beginning of the sentence repeatedly. The word "and" which was placed at the beginning of the sentence is wrong because the function of a conjunction to connect between parts of one another.

Another ignorance experienced by students was to distinguish the use of prepositions and prefixes. There were still many students did mistakes in writing these two different things in writing their essays. According to the rules of Indonesian language, writing for prepositions or prepositions (for example the word "in") must be written separately with the words that follow it (using spaces). Examples of prepositions in question are at school, above, in front of, between, and others. In word context which got a prefix "in", it was connected with the word that follows it as beaten, "manifested", "kicked", and "discriminated against", and so on.

Another mistake also lied in writing the beginning of sentence. At the end of a sentence, the use of periods must be spaces before starting the beginning of the next sentence. In fact, many students did not give space after constructing the end of sentence. Researchers also found capital letters which were not appropriate in student essays. Capital letters were 
used at the beginning of each sentence of the sentence. But there were still some students who did not do it.

\section{CONCLUSION}

The authenticity and logic of the essay written by students can be said to be quite good, out of 25 students, 18 students are able to write with their work, and are good at organizing language so that it contains a unity of logical meaning. Seven other students are still experiencing difficulties in the field of cohesion, coherence so that the writing written is considered illogical.

The completeness of the essay written by the students is said to be quite good, because some students already understand in writing the opening paragraphs, contents, and closing. There are eight students who are still experiencing difficulties in this aspect. This is due to the limitations of the paragraph developed in the opening paragraph or the body of the contents or closing. There are even students without opening and closing paragraphs.

Fill in the essay. In the content, there are nine students out of 25 students who have difficulty in developing topics. In addition to developing topics, student difficulties also occur in the selection of topics that are not interesting and not in accordance with their life experiences. So that the contents lacking ideas, facts and knowledge of the information conveyed.

Language and writing, in this aspect there are 12 students having difficulty in placing the right conjunction, prepositions and prefixes, and punctuation in accordance with their functions. From the results of the analysis of the difficulties in writing the essay, it can be said that the ability of STKIP PGRI Bandar Lampung students in the fourth semester in the ability is quite good.

\section{REFERENCES}

Anggraini, Tri Riya. (2015). Pengembangan Bahan Ajar Menulis Cerita Pendek Kelas X SMA Negeri 2 OKU. Jurnal Didascein, 1(1), 1-12.

Budiyono, Herman. (2012). Mengembangkan Paragraf Sesuai Fungsi dan Posisi dalam Rangka Menulis Sebuah Tulisan Esai. Jurnal Penal, 2(2), Juli. 2012.
Connor, U. (1996). Contrastive Rhetoric: Cross-Cultural Aspects of Second Language Writing. Cambridge: Cambridge University Press.

Dalman. (2011). Keterampilan Menulis. Jakarta: Rajawali Pers.

Dalman. (2012). Keterampilan Menulis. Jakarta: PT Raja Grafindo Persada.

Depdikbud. (1995). Kamus Besar Bahasa Indonesia (KBBI). Jakarta: Balai Pustaka.

Djuharie, O.S. dan Suherli. (2001). Panduan Membuat Karya Tulis: Resensi, Laporan Buku, Skripsi, Tesis, Artikel, Makalah, Berita, Essei, dll. Bandung: Yrama Widya.

Darmadi, Hamid. (2011). Metode Penelitian Pendidikan”. Bandung: Alfabeta.

Helaluddin. (2017) "Analisis struktur esai mahasiswa pada mata kuliah bahasa Indonesia di iain sultan maulana hasanuddin banten. Journal bindo sastra, 1(1), 15-23.

Hs, L. (2005). Gairah Menulis. Yogyakarta: Alinea.

Krashen, S.D. (1981). Writing: Research, Theory, and Applications. Oxford: Pergamon Institute of English.

Khuzaemah, emah dan Lilik Herawati. (2017). "Pembelajaran menulis esai menggunakan model cooperative integrated reading and composition (circ) berbasis life skills". Journal Indonesian Language Education and Literature, 2(2), 148-162.

Meyers, Alan. (2005). Gateways to Academic Writing: Effectives Sentences, Paragraph, and Essays. New York: Longmann.

Nunan, David. (1989). Designing Tasks for the Communicative Classroom. Cambridge: Cambridge University Press.

Oshima, Alice dan Ann Hogue. (2006). Writing Academic English. New York: Longman.

Rachmawati, Dea Triani. (2014). Penerapan Metode Menulis Berantai dalam Meningkatkan Kemampuan Menulis Cerpen. Universitas Pendidikan Indonesia.

Satata, Sri, Devi Suswandari dan Dadi Waras Suharjo. (2012). Bahasa Indonesia untuk Penulisan Akademik di Perguruan Tinggi. Jakarta: Mitra wacana Media.

Slamet, St.Y. (2007). Dasar-dasar Ketrampilan Berbahasa Indonesia. Surakarta: UNS Press.

Sukmadinata, Nana Syaodih. (2011). Metode Penelitian Pendidikan. . Bandung: Rosda.

Suparno dan Mohamad Yunus. (2007). Keterampilan Dasar Menulis. Jakarta: Universitas Terbuka.

Tarigan, Hendry Guntur. (2008). Menulis Sebagai Suatu Keterampilan Berbahasa. Bandung: Angkasa.

Wahyudi Siswanto dan Dewi Ariani. (2016). Model Pembelajaran Menulis Cerita. Malang: Refika Aditama.

Widiati, Utami. (2008) "Pembelajaran Membaca-Menulis Terpadu Melalui Buddy Journals untuk Meningkatkan Kemampuan Menulis Mahasiswa Jurusan Sastra Inggris. Journal BAHASA DAN SENI, Tahun 36, Nomor 2, Agustus 2008".187-188.

Zainurrahman. (2011). Menulis dari Teori Hingga Praktik (Penawar Racun Plagiarisme). Bandung: Alfabeta. 